\title{
Implications of Financial and Non-financial Measures on the Refinement of the Assessments of Audit Risk: An Empirical Investigation
}

\author{
Abdelmoneim A. Awadallah, Haitham Mohamed El-Said \\ Cairo University, Giza, Egypt
}

\begin{abstract}
Identifying and assessing audit risk is a key part of the audit process. Prior research documented that auditors primarily look at financial data, information, and measures when assessing the audit risk for an audit engagement. However, professional standard setters, regulators, and academic researchers have discussed the potential for non-financial data, information, and measures to provide a powerful and independent benchmark for evaluating the validity of the numbers of financial statements of an audit client. A field study was conducted in Egypt during the years 2013 and 2014 to explore how auditors perceive and assess audit risk for an audit engagement in the period following the Egyptian revolution of January 25, 2011. The results of the field study indicated that auditors appear not to give sufficient attention to non-financial data, information, and measures when assessing the audit risk during an audit engagement. Auditors seem to rely on financial data, information, and measures when assessing the audit risk of an audit engagement. Furthermore, auditors do not seem to consider the inconsistencies between financial and non-financial data, information, and measures of an audit client as an indicator of the existence of fraud or material misstatements in the financial statements of an audit client.
\end{abstract}

Keywords: non-financial measures, financial measures, audit risk

\section{Introduction}

Statement on Auditing Standards (SAS) No. 56 (American Institute of Certified Public Accountants [AICPA], 1988) requires the use of analytical procedures in the planning and final review stages of an audit and recommends its use for substantive testing stage. SAS No. 56 indicated that analytical procedures entail consideration of both financial and non-financial data, information, and measures. The Public Company Accounting Oversight Board (PCAOB) has discussed the potential for non-financial data, information, and measures to provide a powerful, independent benchmark for evaluating the validity of financial statements data and information (PCAOB, 2004).

It is claimed in the relevant literature that non-financial data, information, and measures potentially may assist auditors to identify likely trends in the financial statements of an audit client. For instance, a decline in

\footnotetext{
Abdelmoneim A. Awadallah, Ph.D., professor of Managerial Accounting and Economics, Accounting Department, Faculty of Commerce, Cairo University.

Haitham Mohamed El-Said, MA, Accounting Department, Faculty of Commerce, Cairo University.

Correspondence concerning this article should be addressed to Haitham Mohamed El-Said, 54 El Batal Ahmed Abdel Aziz St., Qatar National Bank AlAhli Bulding, Mohandessen, Giza, Egypt. Email: HM_elsaid@hotmail.com. Tel: (02)01005896450.
} 
the demand for the products of a certain industry may suggest downward sales expectations for an audit client within this industry. Accordingly, when non-financial data, information, and measures conflict with financial data, information, and measures (e.g., industry sales are falling but the audit client has increasing sales), the auditor should evaluate both pieces of information to be able to develop correct expectations about account balances of the audit client in question (AICPA, 2002; Libby \& Frederick, 1990). Expectations are then compared to unaudited financial statements to identify significant unexpected fluctuations to be investigated in more details (Cohen, Krishnamoorthy, \& Wright, 2000; Knechel, 2007).

Previous research indicated that when auditors depend on non-financial data, information, and measures in combination with financial data, information, and measures, this would lead to the development of more accurate expectations of the account balances and ratios of an audit client than when depending solely on financial data, information, and measures (Ittner \& Larcker, 1998; Brewster, 2011; Behn \& Riley, 1999). Furthermore, prior studies claimed that firms that commit fraud usually fail to manipulate its non-financial data, information, and measures constantly and that fraud firms should be more likely than non-fraud firms to report financial results that are inconsistent with their non-financial data, information, and measures (Bell, Peecher, \& Solomon, 2005; Brazel, Jones, \& Zimbelman, 2009; Brazel, Jones, \& Prawitt, 2014). Consequently, auditors' consideration of any inconsistencies between a company's financial performance and related non-financial measures could provide a red flag with respect to fraudulent financial reporting (Cohen et al., 2000; Brazel et al., 2009).

Several previous studies showed that auditors generally give insufficient attention to non-financial data, information, and measures when assessing the audit risk for an audit engagement (Hirst \& Koonce, 1996; Bell, Marrs, Solomon, \& Thomas, 1997; Trompeter \& Wright, 2010; Brazel et al., 2014; Erickson, Mayhew, \& Felix, 2000). It is claimed in the literature that if auditors over-rely on financial data, information, and measures and do not incorporate non-financial data, information, and measures when developing expectations for an account balance, an incomplete set of hypotheses may be generated leading to incorrect assessment of the audit risk for an audit engagement (Cohen et al., 2000).

The core problem tackled in the present study is whether auditors' consideration of non-financial as well as financial data, information, and measures could lead to a relative enhancement in auditors' assessment of audit risk within an audit engagement. Furthermore, an attempt is made in the current study to investigate how auditors perceive and react to inconsistencies between the changes in financial and non-financial data, information, and measures of an audit client during the assessment of audit risk.

The main findings of the current study would be that auditors need to give more attention to non-financial data, information, and measures during the assessment of audit risk of an audit engagement. It was recognized that auditors tend to depend more on financial data, information, and measures than on non-financial data, information, and measures in the assessment of audit risk during the planning stage of an audit. In addition, the existence of conflicting trends between financial and non-financial data, information, and measures appears not to lead auditors to perceive that an audit client is committing a fraud or having misstatements in their financial statements.

The remainder of the present research paper is organized as follows: Section 2 presents the research hypotheses; Section 3 sheds light on the research method and data collection procedures; Section 4 shows the results of the current study; Section 5 includes a summary of the present study; and Section 6 consists of the study limitations and recommendations for further research. 


\section{The Development of the Hypotheses}

Client acceptance and continuance decisions are considered to be an important part in determining audit risk for an audit engagement. Because once an auditor enters into an engagement with an audit client, the audit risk cannot be eliminated (Laux \& Newman, 2010). Auditors usually assess audit clients related risks (including financial risk, audit risk, and auditor business risk) before entering into an audit engagement with them. ${ }^{1}$ The main purpose of investigating a new or continuing audit client is to ascertain the integrity of the audit client and to evaluate the possibility of fraud and litigation risks (DeFond, Lim, \& Zang, 2016). It is assumed that auditors usually have relatively good knowledge of their continuing audit clients as they have audited them for at least one year before (Johnstone \& Bedard, 2004; DeFond \& Zhang, 2014). On the other hand, auditors usually have little experience, if any, about new audit clients. For this reason, auditors may need to gather more data and information about a new audit client to be able to determine whether or not to accept this new client. Thus, it may be claimed that auditors assess the audit risk of a continuing audit client in a way that is different from a new audit client. Consequently, the following hypothesis is developed:

H1: There is no significant difference between the way in which auditors assess audit risk for a new audit client and a continuing audit client during an audit engagement.

As emphasized by audit standards and academic research, non-financial data, information, and measures could be used to help auditors understand an audit client's business by pointing them to the drivers of economic performance of an audit client (Ittner \& Larcker, 1998; Riley, Pearson, \& Trompeter, 2003; Brazel et al., 2009; International Auditing and Assurance Standards Board [IAASB], 2010; Knechel, Salterio, \& Kochetova-Kozloski, 2010). Using non-financial data, information, and measures would provide an avenue for auditors to both generate reliable expectations for their analytical procedures and test the validity of management's explanations to their inquiries (Wu, 2004; Brazel et al., 2009; Luft, 2009; Schultz, Bierstaker, \& O’Donnell, 2010).

However, prior research documented that auditors primarily look at financial data, information, and measures when conducting analytical procedures. Brazel et al. (2014) indicated that auditors tend to focus on prior year financial data and information when generating expectations for current year accounts balances. Besides, Cohen et al. (2000) mentioned that auditors relay more heavily on financial data and information than on non-financial data and information in determining audit scope. Since prior research suggested that auditors may rely more heavily on financial data, information, and measures than on non-financial data, information, and measures in assessing the audit risk of an audit engagement, the following hypothesis would seem to be subjected to an appropriate test:

H2: In assessing audit risk, there is no significant difference between the dependence of auditors on financial data, information, and measures and non-financial data, information, and measures.

The PCAOB (2004) contends that comparing financial data to non-financial data is more likely to help auditors detect fraud than performing analytical procedures based solely on financial data that may be subject to manipulation or fraud. Brazel et al. (2009) found that for fraud firms, the percentage of growth in sales differs

\footnotetext{
${ }^{1}$ Financial risk is the risk that a potential client's economic condition will deteriorate in either the short or long term (Johnstone, 2000); it is also referred to as client business risk. Audit risk is "the risk that the auditor may unknowingly fail to appropriately modify his opinion on financial statements that are materially misstated" (AICPA, 1983). Auditor business risk is "the risk that the audit firm will suffer a loss resulting from the engagement” (Johnstone, 2000; AICPA, 1983), and it is significantly higher for publicly traded clients because of their associated litigation risk (Bell, Bedard, Johnstone, \& Smith, 2002).
} 
substantially from the percentage of growth in non-financial measures related to capacity. Likewise, Dechow, Ge, Larson, and Sloan (2011) observed that assets growth for fraud firms differs significantly from the growth in the number of employees for these firms. Both of these studies found that the relations between growth in financial measures and related non-financial measures are closer for companies not committing fraud than for companies committing fraud. On the other hand, Brazel et al. (2014) found that a minority of auditors use non-financial data and information as an information source to extend their substantive testing and that auditors do not appear to increase their reliance on non-financial data and information when the non-financial measures point to a fraud red flag. Given the results of prior studies, the following hypothesis is examined:

H3: Auditors are not judging a business unit that is perceived to have inconsistencies between financial data, information, and measures and non-financial data, information, and measures to be riskier than a business unit that relatively does not have such inconsistencies.

\section{Research Method and Data Collection}

\section{The Development of the Research Method and Pilot Testing}

The current research is based on a questionnaire that was developed by the authors in 2012. The questionnaire included some questions that were used by Trompeter and Wright (2010) and seem to be relevant to the current topic of research. Besides, in the development of the questions of the questionnaire, the authors also went back to the research materials of Brazel et al. (2014). The questionnaire aimed at helping participants express their opinions regarding the different issues examined in the current study using questions based on a 5-point Likert scale where 1 = Rarely, 2 = Sometimes, 3 = Usually, 4 = Frequently, and 5 = Always or through yes or no questions (Bloomfield, Nelson, \& Soltes, 2016).

Pilot testing of the questionnaire was conducted over scattered 20 days during July and August 2012. The pilot testing involved initial in-depth interviews with randomly chosen four participants working in the auditing field in Egypt. The pilot testing resulted in some modifications to the initial questionnaire that were considered in the final version of the questionnaire used in this study.

\section{The Sample and Data Collection}

The authors started sending the final version of the questionnaire to auditors in January 2013. The current study depends on the responses of auditors working at the branches of the international big four auditing firms engaged in audit works in Egypt (i.e., Ernst \& Young, KPMG, PricewaterhouseCoopers, and Deloitte Touche). The total number of complete questionnaires received by the authors over the period from January 2013 to December 2014 was 40. The main reason for this weak response was the lack of free time for auditors to fill such questionnaire due to their highly condensed operating time schedules. This left the vacations and the gaps between audit seasons as the only available time for the auditors to fill the questionnaire or to conduct interviews.

Table 1

Sample Composition

\begin{tabular}{lcc}
\hline Audit title & Frequency & Percent (\%) \\
\hline Audit staff & 5 & 12.5 \\
Senior auditors & 25 & 62.5 \\
Audit managers & 5 & 12.5 \\
Partners & 5 & 12.5 \\
Total & 40 & 100 \\
\hline
\end{tabular}


Descriptive statistics on the sample composition of the present study are presented in Table 1 . The sample is composed of five partners, five audit managers, 25 senior auditors, and five experienced audit staff. The average audit experience of the participants is 9.3 years. Auditors participating in this study were involved in not less than 12 audit engagements during the period from 2012 to 2014.

\section{Results and Discussions}

In interpreting the findings of the current study, each group of questions that appear to be related to the same issue that the questionnaire aims at dealing with was grouped under a title that seems to reflect such issue. Besides, in the presentation of the study results, the questions of the questionnaire are referred to as $\mathrm{Q}$ so that Q1 refers to question No. 1, Q2 refers to question No. 2 and so on. ${ }^{2}$

\section{Auditors' Performance of the Analyses of Financial Data, Information, and Measures During the Planning Stage of an Audit}

The participants were requested to express on a 5-point scale (where $1=$ Rarely, 2 = Sometimes, 3 = Usually, 4 = Frequently, and 5 = Always) to what extent they perform analyses of financial data, information, and measures during the planning stage of an audit. This question was asked to the participants two times: one time regarding new audit clients (Q1) and another time for continuing audit clients (Q2).

Regarding the extent to which auditors perform analyses of financial data, information, and measures for a new audit client (Q1), the mean of the participants' responses was 4.32 and the median was 5. Concerning the performance of analyses of financial data, information, and measures for a continuing audit client (Q2), the mean of the participants' responses was 4.30 and the median was 5 .

A paired sample t-test was employed to compare between participants' responses regarding the performance of analyses of financial data, information, and measures for new audit clients and for continuing audit clients (Q1 and Q2). The result of the paired sample $t$-test was statistically insignificant at a confidence level of $95 \%(p=0.86>0.05)$. This means that there is no statistically significant difference between new and continuing audit clients in relation to the extent to which auditors perform analyses of financial data, information, and measures. Therefore, $\mathrm{H} 1$ is accepted.

\section{Auditors' Performance of the Analyses of Non-financial Data, Information, and Measures During the Planning Stage of an Audit}

Participants were requested to express on a 5-point scale (where 1 = Rarely, 2 = Sometimes, 3 = Usually, $4=$ Frequently, and $5=$ Always) to what extent they perform analyses of non-financial data, information, and measures during the planning stage of an audit. This question was asked to the participants two times: one time in connection with new audit clients (Q3) and another time for continuing audit clients (Q4).

Concerning the extent to which auditors perform analyses of non-financial data, information, and measures for new audit clients (Q3), the mean of the participants' responses was 3.80 and the median was 4 . With reference to the performance of analyses of non-financial data, information, and measures for continuing audit clients (Q4), the mean of the participants' responses was 3.88 and the median was 4. Hence, it could be said that auditors are likely to perform analyses of non-financial data and information for both new and continuing audit clients during the planning stage of an audit.

\footnotetext{
2 The results of the current study are presented based on the sequence of the questions of the questionnaire and not according to the sequence of the hypotheses.
} 
A paired sample t-test was performed to compare between the responses of the participants in relation to the extent to which they perform the analyses of non-financial data, information, and measures for new audit clients and for continuing audit clients (Q3 and Q4). The result of the paired sample $t$-test was statistically insignificant at a confidence level of $95 \%(p=0.372>0.05)$. This result indicates that there is no significant difference between the extent to which auditors analyze non-financial data, information, and measures for new audit clients and for continuing audit clients. Consequently, H1 is accepted.

\section{Comparing Auditors' Dependence on Financial Data, Information, and Measures Against Non-financial Data, Information, and Measures in Assessing Audit Risk}

To compare between auditors' reliance on financial data, information, and measures against auditors' reliance on non-financial data, information, and measures in the assessment of audit risk for an audit client, the following was done:

(1) The responses of the participants related to the analyses of financial data, information, and measures for new and continuing audit clients (Q1 and Q2) were composed to form one new variable named: "the analyses of financial data, information, and measures";

(2) The responses of the participants related to the analyses of non-financial data, information, and measures for new and continuing audit clients (Q3 and Q4) were composed to form one new variable named: "the analyses of non-financial data, information, and measures".

A paired sample $t$-test was performed to investigate if there is a significant difference between "the analyses of financial data, information, and measures" and "the analyses of non-financial data, information, and measures".

The results of paired sample $t$-test indicated that there is a statistically significant difference in the scores between the analyses of financial data, information, and measures $(M=6.475, S D=1.154)$ and the analyses of non-financial data, information, and measures $(M=5.71, S D=1.42)$ in favor of the analyses of financial data, information, and measures $(p=0.003<0.05, t=3.15)$. This result may signify that auditors are more likely to depend on financial data, information, and measures than on non-financial data, information, and measures in the assessment of the audit risk of an audit client during the planning phase of an audit. As a result, H2 is rejected.

The results of the current study appear to be consistent with the results of previous studies regarding the reliance of the auditors on financial data, information, and measures during the assessment of audit risk. Various prior studies documented that auditors primarily look at financial data, information, and measures when assessing audit risk during the planning stage of an audit (Hirst \& Koonce, 1996; Cohen et al., 2000; Trompeter \& Wright, 2010; Brazel et al., 2014). Cohen et al. (2000) mentioned that this may be due to auditors training and greater familiarity with financial than non-financial data and information since auditors' primary role is to provide an opinion on the financial statements of an audit client.

\section{The Performance of the Analyses of Financial Data, Information, and Measures by Different Levels of Audit Personnel}

The participants were requested to identify, according to their perception, the percentage of the analyses of financial data, information, and measures done by each of the audit staff, senior auditors, audit managers, and audit partners during the planning stage of an audit. The participants were asked this question twice: one time for new audit clients (Q5) and another time for continuing audit clients (Q6). 
In relation to new audit clients, the mean of the participants' responses revealed that audit staff performs about $27 \%$ of the analyses of financial data, information, and measures for new audit clients, while senior auditors perform about $44 \%$, audit managers $21 \%$, and partners $8 \%$ of the analyses of financial data, information, and measures for new audit clients.

For continuing audit clients, the mean of participants' responses showed that audit staff performs about $32 \%$ of the analyses of the financial data, information, and measures, while about $47 \%$ of the analyses are done by senior auditors. Moreover, audit managers and partners do on average $16 \%$ and $5 \%$ respectively of the analyses of financial data, information, and measures for continuing audit clients.

The above results seem to be somehow surprising although such results are consistent with the results of prior studies. Hirst and Koonce (1996) reported that 25 of 25 participants indicated that, in the planning stage of an audit, analytical procedures were usually performed by senior auditors or audit managers with audit managers being more involved in case of high risk audit clients. Furthermore, Trompeter and Wright (2010) found that analytical procedures are performed primarily by audit staff and senior auditors (48\% and 35\% respectively) with less of this work being done by managers (12\%) and partners (5\%). Trompeter and Wright (2010, p. 687) stated that:

There has been an increase in the tendency to assign APs [analytical procedures] to less experienced staff. It appears that firms are more comfortable in assigning this work to associates, perhaps because they have increased their investments in training junior associates.

On the other hand, Trompeter and Wright (2010) mentioned that it may be a cause for concern if profitability concerns are driving audit firms to assign less qualified staff to conduct more complex audit procedures.

To observe if there is a statistically significant difference between new audit clients and continuing audit clients in respect of the percentage of the analyses of financial data, information, and measures done by each of the different levels of the audit personnel, a paired sample $t$-test was used. The significance level used for this test was $5 \%$. The results of the paired sample $t$-test showed that there is a statistically significant difference in favor of new audit clients for each of audit managers ( $p=0.019, t=2.44)$ and partners $(p=0.02, t=2.42)$. In contrast, there was no statistically significant difference between new audit clients and continuing audit clients in relation to the percentage of analyses of financial data, information, and measures done by each of the audit staff ( $p=0.081, t=-1.79)$ and senior auditors ( $p=0.305, t=-1.04)$.

The results of the pair sample $t$-test seem to be reasonable as audit managers and partners are usually responsible for new clients' acceptance/rejection decisions. Therefore, audit managers and partners may be involved in the performance of greater percentage of the analyses of financial data, information, and measures for new audit clients than for continuing audit clients. Thus, $\mathrm{H} 1$ is rejected.

\section{The Performance of the Analyses of Non-financial Data, Information, and Measures by Different Levels of Audit Personnel}

The participants were requested to identify, according to their perception, the percentage of the analyses of non-financial data, information, and measures done by each of the audit staff, senior auditors, audit managers, and partners during the planning stage of an audit. The participants were asked this question two times: one time for new audit clients (Q7) and another time for continuing audit clients (Q8). 
For new audit clients, the mean of the participants' responses showed that audit staff performs about $24 \%$ of the analyses of non-financial data, information, and measures for new audit clients, while senior auditors perform about $43 \%$. In addition, the mean of the participants' responses pointed out that audit managers do about $22 \%$ and partners $11 \%$ of the analyses of non-financial data, information, and measures for new audit clients.

For continuing audit clients, the mean of the participants' responses showed that audit staff performs $28 \%$ of the analyses of the non-financial data, information, and measures, while about $49 \%$ of the analyses are done by senior auditors. Furthermore, participants stated that audit managers carry out on average 16\% and partners about $7 \%$ of the analyses of non-financial data, information, and measures for continuing audit clients.

To examine whether there is a statistically significant difference between new audit clients and continuing audit clients in relation to the percentage of the analyses of non-financial data, information, and measures performed by the different levels of the audit personnel, a paired sample $t$-test was employed. Using significance level of $5 \%$, the results of the paired sample $t$-test were statistically significant in favor of new audit clients for audit managers ( $p=0.008, t=2.77)$ and partners $(p=0.009, t=2.73)$. On the other hand, the results were statistically significant in favor of continuing audit clients for each of the audit staff $(p=0.009, t=2.75)$ and senior auditors ( $p=0.032, t=2.23$ ).

The results imply that audit managers and partners perform a greater percentage of the analyses of non-financial data, information, and measures for new audit clients to be able to identify potential audit risk related to new audit clients. On the other hand, it appears that for continuing audit clients, audit managers and partners may delegate the performance of some of the analyses of non-financial data, information, and measures to senior auditors and audit staff when applicable. Of course, it might be said that the delegation of duties from audit managers and partners to senior auditors and audit staff is usually due to the highly condensed operating time schedules of the audit managers and partners. However, such delegation of duties from audit managers and partners to senior auditors and audit staff should not be on the expense of the audit quality. Therefore, it can be said that $\mathrm{H} 1$ is rejected as it seems that auditors assess audit risk differently for new audit clients than for continuing audit clients.

\section{The Analyses of Conflicting Trends Between Financial and Non-financial Data, Information, and Measures to Identify Material Misstatements}

A series of questions were directed to the participants of the present study to examine how auditors evaluate the relation between financial and non-financial data, information, and measures when assessing audit risk for an audit engagement.

In Question 9, participants were inquired if they analyze financial and non-financial data, information, and measures of the current year to find out any conflicting trends between them (Q9). All the participants answered this question by "Yes", indicating that they analyze financial and non-financial data, information, and measures of the current year to find out any conflicting trends between them.

Participants were requested to express on a 5-point scale (where 1 = Rarely, 2 = Sometimes, $3=$ Usually, $4=$ Frequently, and $5=$ Always) to what extent they analyze financial and non-financial data, information, and measures of the current year to find out any conflicting trends between them. The mean of the participants' responses was 3.82 and the median was 4 . 
In Question 10, participants were asked: "Would the existence of conflicting trends between current year financial and non-financial data, information, and measures affect an auditor judgment of the existence of any fraud?” (Q10). Concerning Q10, 87.5\% of the participants answered "Yes", while 12.5\% answered "No". Participants who answered "Yes" were requested to express on a 5-point scale (where 1 = Rarely, 2 = Sometimes, 3 = Usually, $4=$ Frequently, and 5 = Always) to what extent the existence of conflicting trends between financial and non-financial data, information, and measures would affect their judgment of the existence of any fraud? The mean of the participants' responses was 3.49 and the median was 4 .

A Spearman correlation was employed to examine the association between auditors' performance of the analyses of financial and non-financial data, information, and measures to find conflicting trends between them (Q9) and auditors' judgment of the existence of fraud based on conflicting trends between financial and non-financial data, information, and measures (Q10). ${ }^{3}$ The results showed that the correlation was statistically insignificant at a confidence level of $95 \%(p=0.162>0.05)$. This result revealed that there is an insignificant association between auditors' analyses of financial and non-financial data, information, and measures to find conflicting trends between them and the auditors' judgment that the audit client is committing a fraud as a result of the conflicting trends between financial and non-financial data, information, and measures. Thus, H3 is accepted.

The current research result is consistent with the findings of previous studies. Hirst and Koonce (1996, p. 463) stated that:

Auditors spend considerable time gathering and evaluating financial and nonfinancial information about the client and its industry. However, when they develop their expectations for account balances or ratios, we observed that they tend not to rely heavily on such information. Twenty-five of 26 auditors indicated that APs [Analytical Procedures] at planning are generally performed account by account at the financial statement level for both the balance sheet and income statement.

Trompeter and Wright (2010) mentioned that auditors are still reporting that they depend heavily on prior year balances when developing expectations for current year account balances (in this case, auditors would be unlikely to respond to conflicting trends between financial data, information, and measures and related non-financial data, information, and measures). Brazel et al. (2014) found that only a minority of senior auditors choose to use non-financial measures when evaluating revenue account balances via analytical procedures.

Participants were asked in Q11: Would the analyses of non-financial data, information, and measures shed light on areas where material misstatements might exist? 95\% of the participants replied "Yes" and only 5\% replied "No". Participants who replied "Yes" were requested to express using a 5-point scale (where $1=$ Rarely, 2 = Sometimes, 3 = Usually, 4 = Frequently, and 5 = Always) to what extent the analyses of non-financial data and information would shed light on areas where material misstatements might exist. The mean of the participants' responses was 3.2 and the median was 3.

A spearman correlation was utilized to examine if there is a relationship between auditors' judgment of the existence of fraud based on conflicting trends between financial and non-financial data, information, and measures (Q10) and the auditors' dependence on non-financial data, information, and measures in the detection of misstatements (Q11). ${ }^{4}$ The results showed that the Spearman's correlation coefficient, $r_{\mathrm{s}}$, was 0.761 , and the correlation was statistically significant at the confidence level of $95 \%(p=0.01<0.05)$. Thus, there is a

\footnotetext{
${ }^{3}$ In performing the Spearman correlation between the responses of the participants in Q9 and Q10 listwise exclusion was performed for missed cases. Accordingly, the correlation was done between variables of equal sample size $(n=35)$.

${ }^{4}$ When performing Spearman correlation between Q10 and Q11 listwise exclusion was performed for missed cases. Thus, the correlation was done between variables of equal sample size $(n=33)$.
} 
positive correlation between the variables. This result points out that in case auditors can judge that there is a sign of fraud as a result of conflicting trends between financial and non-financial data, information, and measures, auditors may depend on non-financial data, information, and measures to shed light on areas where material misstatements might exist.

This result is consistent with what is asserted in the literature regarding non-financial data, information, and measures. Ittner and Larcker (1998) mentioned that non-financial data and information could be used to help auditors understand an audit client's business by pointing them to the drivers of economic performance of an audit client. Cohen et al. (2000) mentioned that auditors make more use of non-financial information when generating hypotheses to explain unexpected fluctuations within the financial statements of an audit client than when determining audit scope. Brazel et al. (2009) mentioned that if non-financial measures are correlated with financial performance, and auditors can detect unusual fluctuations in non-financial measures compared with reported financial performance, then non-financial measures may be an indicator of the existence of fraud risk.

\section{The Effect of Declining Trends of Financial and Non-financial Data and Information on Auditors' Perception of Misstatement}

In Question 12, participants were inquired: If financial trends are declining in relation to the company you are auditing, would this imply the existence of misstatements? (Q12). As for this question, $57.5 \%$ of the participants answered "Yes", while 42.5\% answered "No". For participants who answered "Yes", they were requested to express on a 5-point scale (where $1=$ Rarely, $2=$ Sometimes, $3=$ Usually, $4=$ Frequently, and 5 = Always) to what extent would declining financial trends imply the existence of misstatements for an audit client? The mean of the participants' responses was 3.26 and the median was 3.

In Question 13, participants were inquired: If non-financial trends of an audit client are declining, would this imply the existence of misstatements in the audit client financial statements? (Q13). Concerning Q13, 65\% of the participants replied "Yes", while 35\% replied "No". For participants who answered "Yes", they were requested to express on a 5-point scale (where $1=$ Rarely, $2=$ Sometimes, $3=$ Usually, $4=$ Frequently, and 5 = Always) to what extend would a declining non-financial trend imply the existence of misstatements for an audit client? The mean of the participants' responses was 2.77 and the median was 3 .

Paired sample $t$-test was used to compare the effect of declining financial trends (Q12) against the effect of declining non-financial trends (Q13) on auditors' perception of the existence of misstatements in the financial statements of an audit client. The result of the paired sample $t$-test was statistically insignificant at the confidence level of $95 \%$ ( $p=0.088, t=1.793)$. This shows that there is no significant difference between the effect of declining financial trends and declining non-financial trends on auditors' perception of the existence of misstatements for an audit client. Thus, H2 is accepted. Cohen et al. (2000) pointed out that when auditors are generating hypotheses to explain unexpected fluctuations during an audit engagement, auditors tend to generate equal number of hypotheses when either financial or non-financial trends are declining.

\section{Developing Expectations for Sales Revenue Account Balances}

Two questions were asked to the participants to check what audit techniques are most used by auditors when developing expectations about the balances of sales revenue account of an audit client during an audit. Participants were required to express using a 5-point scale (where $1=$ Rarely, 2 = Sometimes, 3 = Usually, $4=$ Frequently, and $5=$ Always) the extent to which auditors depend on each of the following five audit techniques in developing their expectations for account balances: 
(1) Comparison of balances;

(2) Analysis of ratios;

(3) Consideration of non-financial data, information, and measures;

(4) Budgets and forecasts prepared by the client;

(5) Interim data.

In relation to the development of expectations for sales revenue account balances for a new audit client (Q14), the mean of the participants' responses regarding the use of each of the audit techniques is presented hereunder in a descending order (see Table 2).

Table 2

The Mean of the Participants' Responses for the Use of Audit Techniques in the Development of Expectations for the Sales Revenue Account Balances for a New Audit Client

\begin{tabular}{lc}
\hline Technique & Mean \\
\hline Comparison of balances & 4.55 \\
Analysis of ratios & 3.98 \\
Interim data & 3.95 \\
Consideration of non-financial data, information, and measures & 3.50 \\
Budgets and forecasts prepared by the client & 3.25 \\
\hline
\end{tabular}

Furthermore, regarding the development of expectations for sales revenue account balances for continuing audit clients (Q15), the mean of the participants' responses for the use of each of the audit techniques is presented hereunder in a descending order (see Table 3).

Table 3

The Mean of the Participants' Responses for the Use of Audit Techniques in the Development of Expectations for the Sales Revenue Account Balances for a Continuing Audit Client

\begin{tabular}{lc}
\hline Technique & Mean \\
\hline Comparison of balances & 4.60 \\
Analysis of ratios & 4.00 \\
Interim data & 3.90 \\
Consideration of non-financial data, information, and measures & 3.50 \\
Budgets and forecasts prepared by the client & 3.40 \\
\hline
\end{tabular}

A paired sample $t$-test was employed to check if auditors' usage of the above audit techniques differs between new audit clients (Q14) and continuing audit clients (Q15) in developing expectations for sales revenue account balances. The results of the paired sample $t$-test showed no statistically significant difference between new and continuing audit clients for all of the above audit techniques at the confidence level of 95\%. Thus, it might be said that auditors seem to use each of the above audit techniques in the same manner for new and continuing audit clients when developing expectations for sales revenue accounts. Accordingly, H1 is accepted.

A paired sample $t$-test was performed to compare between auditors' consideration of non-financial data, information, and measures from one side and each of the comparison of balances, budgets and forecasts, analysis of ratios and interim data in developing expectations for sales revenue account balances. The results of the paired sample $t$-test indicated that there is a statistically significant difference in favor of each of 
comparison of balances ( $p=0.000, t=-5.536)$ and analysis of ratios $(p=0.002, t=-3.387)$ against the consideration of non-financial data, information, and measures during the development of expectations for sales revenue account balances in an audit engagement. Hence, $\mathrm{H} 2$ is rejected as auditors seem to depend more on financial data, information, and measures than non-financial data, information, and measures in developing expectations for sales revenue account balances.

\section{Summary}

The current study is based on a field study that was performed in Egypt to investigate auditors' perception of the audit risk during the period of economic slowdown following the Egyptian revolution of January 25, 2011. Besides, the present study aims at exploring how auditors in Egypt depend on non-financial data, information, and measures in the assessment of audit risk. Additionally, the current study examines how auditors react to inconsistencies between financial and non-financial data, information, and measures of an audit client during the assessment of audit risk.

A questionnaire was developed and distributed over auditors working in the branches of the big four auditing firms in Egypt during the years 2013 and 2014. The responses of the auditors were statistically analyzed using SPSS software. The results of the statistical analyses of the auditors' responses to the questionnaire were explained in light of the hypotheses set for the present study in addition to the findings of previous studies.

The results of the present study could be summed in the following points:

(1) Auditors do not seem to differentiate between new audit clients and continuing audit clients during the assessment of audit risk. Although results indicated that for new audit clients, audit managers and partners perform a greater portion of the analyses of financial and non-financial data, information, and measures than for continuing audit clients;

(2) Auditors appear to be depending more on financial data, information, and measures than on non-financial data, information, and measures in their assessment of the risk of material misstatements of the financial statements of an audit client;

(3) The existence of conflicting trends between financial and non-financial data, information, and measures seems not to lead auditors to judge that an audit client is committing a fraud or having misstatements. Auditors seem not to give sufficient attention to the inconsistencies between financial and non-financial data, information, and measures as an indicator of fraud or material misstatements in the financial statements of an audit client.

It may be said that the main finding of the current study is that it appears that auditors need to give more attention to non-financial data, information, and measures in their assessment of audit risk for an audit engagement. The non-financial data, information, and measures may be vital for auditors to detect misstatements that may be found in the financial statements of an audit client, especially in cases of deteriorating economic conditions. It is recommended for auditing firms to provide auditors with training sessions regarding how to collect and analyze non-financial data, information, and measures. Such training sessions about non-financial data, information, and measures would increase the awareness of the auditors about the role non-financial data, information, and measures may have in verifying the validity of the financial performance of an audit client. 


\section{Current Research Limitations and Suggestions for Future Research}

This part highlights some limitations that should be taken into consideration when looking at the results of the current study in addition to some recommendations for future research:

(1) The present research is only limited to the planning phase of the audit. Future research could be extended beyond the planning phase of the audit process to cover how auditors consider non-financial data, information, and measures during other phases of the audit process such as the substantive testing phase or the overall review phase;

(2) The results of the current study should not be generalized as the sample size used in the study is considered relatively small (only 40 participants). It is recommended for future research to use larger sample size and to use other research techniques such as laboratory experiments or in-depth interviews;

(3) The current study was based on a sample that is dominated by senior auditors and experienced audit staff (six experienced audit staff and 25 senior auditors). Consequently, a sample that is based on more experienced audit personnel such as audit managers and partners may lead to different results.

\section{References}

American Institute of Certified Public Accountants [AICPA]. (1983). Audit risk and materiality in conducting an audit. Statement on Auditing Standards (SAS) No. 47. New York, NY: AICPA.

American Institute of Certified Public Accountants [AICPA]. (1988). Analytical procedures. Statement on Auditing Standards (SAS) No. 56. New York, NY: AICPA.

American Institute of Certified Public Accountants [AICPA]. (2002). Consideration of fraud in a financial statement audit. Statement on Auditing Standards (SAS) No. 99. New York, NY: AICPA.

Behn, B. K., \& Riley, R. A. (1999). Using nonfinancial information to predict financial performance: The case of the U.S. airline industry. Journal of Accounting, Auditing and Finance, 14(1), 29-56.

Bell, T. B., Bedard, J. C., Johnstone, K. M., \& Smith, E. F. (2002). KRiskSM: A computerized decision aid for client acceptance and continuance risk assessments. Auditing: A Journal of Practice \& Theory, 21(2), 97-113.

Bell, T. B., Marrs, F. O., Solomon, I., \& Thomas, H. (1997). Auditing organizations through a strategic-systems lens. New York, NY: KPMG Peat Marwick LLP.

Bell, T. B., Peecher, M. E., \& Solomon, I. (2005). The 21st century public company audit: Conceptual elements of KPMG's global audit methodology. Montvale, NJ: KPMG.

Bloomfield, R., Nelson, M. W., \& Soltes, E. (2016). Gathering data for archival, field, survey, and experimental accounting research. Journal of Accounting Research, 54(2), 341-395.

Brazel, J. F., Jones, K. L., \& Prawitt, D. F. (2014). Auditors' reactions to inconsistencies between financial and nonfinancial measures: The interactive effects of fraud risk assessment and a decision prompt. Behavioral Research in Accounting, 26(1), 131-156.

Brazel, J. F., Jones, K. L., \& Zimbelman, M. F. (2009). Using nonfinancial measures to assess fraud risk. Journal of Accounting Research, 47(5), 1135-1166.

Brewster, B. E. (2011). How a systems perspective improves knowledge acquisition and performance in analytical procedures. The Accounting Review, 86(3), 915-943.

Cohen, J. R., Krishnamoorthy, G., \& Wright, A. M. (2000). Evidence on the effect of financial and nonfinancial trends on analytical review. Auditing: A Journal of Practice \& Theory, 19(1), 27-48.

Dechow, P. M., Ge, W., Larson, C. R., \& Sloan, R. G. (2011). Predicting material accounting misstatements. Contemporary Accounting Research, 28(1), 17-82.

DeFond, M. L., Lim, C. Y., \& Zang, Y. (2016). Client conservatism and auditor-client contracting. The Accounting Review, 91(1), 69-98.

DeFond, M., \& Zhang, J. (2014). A review of archival auditing research. Journal of Accounting and Economics, 58(2-3), 275-326.

Erickson, M., Mayhew, B. W., \& Felix, W. L. (2000). Why do audits fail? Evidence from Lincoln Savings and Loan. Journal of Accounting Research, 38(1), 165-194. 
Hirst, E., \& Koonce, L. (1996). Audit analytical procedures: A field investigation. Contemporary Accounting Research, 13(2), 457-486.

International Auditing and Assurance Standards Board [IAASB]. (2010). International Standard on Auditing 315: Identifying and assessing the risks of material misstatement through understanding the entity and its environment. Retrieved from http://www.ifac.org/sites/default/files/downloads/a017-2010-iaasb-handbook-isa-315.pdf

Ittner, C. D., \& Larcker, D. F. (1998). Are nonfinancial measures leading indicators of financial performance? An analysis of customer satisfaction. Journal of Accounting Research, 36, 1-35.

Johnstone, K. M. (2000). Client-acceptance decisions: Simultaneous effects of client business risk, audit risk, auditor business risk, and risk adaptation. Auditing: A Journal of Practice \& Theory, 19(1), 1-25.

Johnstone, K. M., \& Bedard, J. C. (2004). Audit firm portfolio management decisions. Journal of Accounting Research, 42(4), 659-690.

Knechel, W. R. (2007). The business risk audit: Origins, obstacles, and opportunities. Accounting, Organizations and Society, 32(4-5), 383-408.

Knechel, W. R., Salterio, S. E., \& Kochetova-Kozloski, N. (2010). The effect of benchmarked performance measures and strategic analysis on auditors' risk assessments and mental models. Accounting, Organizations and Society, 35(3), 316-333.

Laux, V., \& Newman, D. P. (2010). Auditor liability and client acceptance decisions. The Accounting Review, 85(1), 261-285.

Libby, R., \& Frederick, D. M. (1990). Experience and the ability to explain audit findings. Journal of Accounting Research, 28(2), 348-367.

Luft, J. (2009). Nonfinancial information and accounting: A reconsideration of benefits and challenges. Accounting Horizons, 23(3), 307-325.

Public Company Accounting Oversight Board [PCAOB]. (2004). PCAOB Standing Advisory Group Meeting: Financial fraud. Retrieved from http://pcaobus.org/News/Events/Documents/09082004_SAGMeeting/Fraud.pdf

Riley, R. A., Pearson, T. A., \& Trompeter, G. (2003). The value relevance of non-financial performance variables and accounting information: The case of the airline industry. Journal of Accounting and Public Policy, 22(3), 231-254.

Schultz, J. J., Bierstaker, J. L., \& O’Donnell, E. (2010). Integrating business risk into auditor judgment about the risk of material misstatement: The influence of a strategic-systems-audit approach. Accounting, Organizations and Society, 35(2), $238-251$.

Trompeter, G., \& Wright, A. (2010). The world has changed-Have analytical procedure practices? Contemporary Accounting Research, 27(2), 669-700.

Wu, C. (2004). Using non-financial information to predict bankruptcy: A study of public companies in Taiwan. International Journal of Management, 21(2), 194-201. 